\title{
HIGH-MANNOSE TYPE N-GLYCAN BINDING SPECIFICITY OF A NOVEL LECTIN FROM THE RED ALGA (BETAPHYCUS GELATINUS)
}

\author{
Le Dinh Hung ${ }^{1, \bigotimes}$, Le Thi Doan Thuc ${ }^{2}$ \\ ${ }^{I}$ Nha Trang Institute of Technology Research and Application, Vietnam Academy of Science and Technology \\ ${ }^{2}$ Ly Tu Trong High School, Khanh Hoa
}

${ }^{\circledR}$ To whom correspondence should be addressed. E-mail: ledinhhungims@yahoo.co.uk

Received: 19.3.2019

Accepted: 17.7.2019

SUMMARY

The red alga, Betaphycus gelatinus is one of carrageenan sources in the world. The lectin from the red alga $B$. gelatinus was isolated by a combination of aqueous ethanol extraction, ethanol precipitation, ion-exchange chromatography and gel filtration chromatography and was designated as BGL after the specific name of alga. Lectin gave a single band with molecular mass of about 19,000 Da in both non-reducing and reducing SDSPAGE conditions, therefore lectin exists in monomer form. The hemagglutination activities of BGL were stable over a wide range of $\mathrm{pH}$ from 3 to 10 , temperature up $60^{\circ} \mathrm{C}$ and not affected by either the presence of EDTA or addition of divalent cations, indicating that lectin requires no metal for biological activity. The hemagglutination activities of BGL were not inhibited by monosaccharides and glycoproteins, D-glucose, Dmannose, D-galactose, D-xylose, N-acetyl-galactosamine, N-acetyl-glucosamine, N-acetyl-neuraminic acid, Nacety-D-mannosamine, transferrin and fetuin, but strongly inhibited by glycoproteins bearing high-mannose type N-glycan, such as yeast mannan and porcine thyroglobulin. Lectin BGL is specific for N-glycans and may recognize terminal $(\alpha 1-3)$ or ( $\alpha 1-6)$-linked mannose residues in structure $\operatorname{Man}(\alpha 1-6)[\operatorname{Man}(\alpha 1-3)] \operatorname{Man}(\alpha 1$ 6)[Man( $(\alpha 1-3)] \operatorname{Man}(\beta 1-4)$ GlcNAc( $\beta 1-4)$ GlcNAc of N-glycans. High-mannose type N-glycan binding specificities of this lectin highly resemble with those of the anti-cancer, anti-virus and anti-bacteria lectins from the red algae, carrageenophytes, including Eucheuma serra (ESA-2), Eucheuma denticulatum (EDA-2), Kappaphycus striatum (KSA-2), Kappaphycus alvarezii (KAA-1 and KAA-2) and Solieria filiformis (SfL1 and SfL2). The red alga B. gelatinus could promise to be a good source of valuable lectins for application in biochemistry and biomedicine.

Keywords: Betaphycus gelatinus; carbohydrate-binding specificity; high-mannose type N-glycan; lectin; red alga; stable

\section{INTRODUCTION}

Lectins, or carbohydrate-binding proteins, are present in various organisms from virus to mammal, and serve as recognition molecules between cells, cell and matrix, and organisms. Owing to the capability of discriminating carbohydrate structures, not only are lectins used as valuable biochemical reagents in many research fields, including glycomics, but they are promising candidates for medicinal and clinical application (Sharon, Lis, 2003).

Indeed, anti-human immunodeficiency virus (HIV) and/or anti-influenza virus lectins from bacteria, algae, fungi, and land plant have the common property of binding to high-mannose $\mathrm{N}$ - glycans, thereby blocking the entry of viruses into host cells through binding to the mannose structures in the viral envelope, which are critical for the primary infection of viruses (Ziolkowska, Wlodawer, 2006; Balzarini, 2007). Recently, the high-mannose $\mathrm{N}$-glycan-specific lectins from the marine algae, such as Eucheuma serra (ESA-2) (Sugahara et al., 2001; Fukuda et al., 2006; Hori et al., 2007;Omokawa et al., 2010; Hayashi et al., 2012; Sato et al., 2015), Kappaphycus alvarezii (KAA-2) (Sato et al., 2011a; Hirayama et al., 2016), Boodlea coacta (BCA) (Sato et al., 2011b), Kappaphycus striatum and Eucheuma denticulatum (Le Dinh Hung et al., 2011, 2015a, 2015b), Halimeda renschii (HRL) (Mu et al., 2017) and Solieria filiformis (SFL) (Chaves et al., 2018) showed strong anti-HIV, anti-influenza virus, anti- 
cancer and anti-bacteria activities through binding to high-mannose chains on viral envelopes or on the surface of the carcinoma cells. Thus, high-mannose binding lectins from marine algae may become a useful interesting target for application in medicine.

Vietnam is located in the tropical and subtropical zone with a long coast line of about $3,260 \mathrm{~km}$, where there is a diversity of marine algae (Huynh Quang Nang, Nguyen Huu Dinh, 1998). These species may be potential sources of biologically active compounds including lectins. However, very little information is known concerning lectins from Vietnamese marine organisms, except several reports on the screening results of hemagglutinins from Vietnamese marine algae and invertebrates (Le Dinh Hung et al., 2009a, 2012; Dinh Thanh Trung et al., 2017), the purification and characterization of lectins from the red algae $K$. alvarezii, $K$. striatum, E. denticulatum, Gracilaria salicornia, Hydropuntia eucheumatoides and from marine sponge Stylissa flexibilis (Le Dinh Hung et al., 2009b, 2011, 2013, 2015a, 2018a, $2018 b$ ), the cDNA clones encoding lectins from $K$. striatum and E. denticulatum (Le Dinh Hung et al., 2015a, 2015b, 2016) and seasonal variations in lectin contents from the cultivated red algae $K$. alvarezii and K. striatus (Le Dinh Hung et al., 2009c, 2019). Thus, the objective of present research was to report on the isolation, biochemical properties and high mannose $\mathrm{N}$-glycan binding specificity of a new lectin from the red alga Betaphycus gelatinus, which can provide valuable information regarding lectins from the carrageenophyte algal family.

\section{MATERIALS AND METHODS}

\section{Materials}

The red alga, Betaphycus gelatinus (Esper) Doty ex P.C.Silva was collected at the coast of Ninh Hai district $\left(109^{\circ} 02^{\prime} 01^{\prime \prime} \mathrm{E}, 11^{\circ} 35^{\prime} 23^{\prime \prime} \mathrm{N}\right)$, Ninh Thuan province, Viet Nam in April, 2018, and kept at - 20 ${ }^{\circ} \mathrm{C}$ until used. The species were identified by Le Nhu Hau (Nha Trang Institute of Technology Research and Application). Prepacked columns used were Sephacryl S-200 $(1.6 \times 60 \mathrm{~cm})$ and DEAE Sepharose fast flow ion exchange chromatographic column $(1.6 \times 20 \mathrm{~cm})$ from GE Healthcare (Sweden). Animal blood was obtained from the Institute of VaccineNha Trang, Viet Nam and human A, B and O blood from Khanh Hoa General Hospital, Viet Nam. The monosaccharides, D-glucose, D-mannose, D- galactose, N-acetyl-D-glucosamine, N-acetyl-Dmannosamine, N-acetyl-D-galactosamine and glycoproteins, transferrin, fetuin, porcine thyroglobulin, and porcine stomach mucin (type III) were purchased from Sigma Chemical Co. Yeast mannan and $\mathrm{N}$-acetyl-neuraminic acid were from Nacalai Tesque Chemical Co. Asialo-derivatives of transferrin, fetuin and porcine stomach mucin were prepared by hydrolysis of the parent sialoglycoprotein with $0.05 \mathrm{M} \mathrm{HCl}$ for $1 \mathrm{~h}$ at $80^{\circ} \mathrm{C}$, followed by dialysis against saline overnight.

\section{Extract and purification of lectin}

Lectin was purified as method described previously (Le Dinh Hung et al., 2018a). Algal material was extracted with $20 \%$ cold ethanol and kept at $4^{\circ} \mathrm{C}$ for $18 \mathrm{~h}$ with occasionally stirring. The filtrate was centrifuged at $6,000 \mathrm{rpm}$ for $20 \mathrm{~min}$ at $4^{\circ} \mathrm{C}$ and was precipitated by cold absolute ethanol ($20^{\circ} \mathrm{C}$ ). The precipitate was collected by centrifugation and thoroughly dialyzed against 20 $\mathrm{mM}$ carbonate buffer $(\mathrm{pH} 9.0)$. The fraction in the dialyzed bag was applied to a DEAE Sepharose fast flow ion exchange chromatographic column $(1.6 \times 20$ $\mathrm{cm})$, equilibrated with the above buffer. Lectin was eluted with a linear gradient between 0 to $0.5 \mathrm{M}$ $\mathrm{NaCl}$ in $20 \mathrm{mM}$ carbonate buffer, $\mathrm{pH} 9.0$ for $20 \mathrm{~min}$; the active fractions were pooled, concentrated by ultrafiltration and dialyzed against $50 \mathrm{mM}$ phosphate buffer containing $150 \mathrm{mM} \mathrm{NaCl}(\mathrm{pH}$ 7.0). The concentrate was applied to gel filtration chromatography on a Sephacryl S-200 column $(1.6 \times 60 \mathrm{~cm})$. The column was eluted with $50 \mathrm{mM}$ phosphate buffer containing $150 \mathrm{mM} \mathrm{NaCl}(\mathrm{pH} 7.0)$ and the active fractions were collected. The eluate was monitored for absorbance at $280 \mathrm{~nm}$ for protein and for hemagglutination activity with trypsintreated rabbit erythrocytes. Active fractions were pooled and subjected to further analysis.

\section{Preparation of a $2 \%$ suspension of native or enzyme-treated erythrocytes}

Each blood sample was washed three to five times with solution of $150 \mathrm{mM} \mathrm{NaCl}$. After washing, a $2 \%$ erythrocyte suspension $(\mathrm{v} / \mathrm{v})$ was prepared in $20 \mathrm{mM}$ phosphate buffer containing $150 \mathrm{mM} \mathrm{NaCl}$ (pH 7.2) and used as native erythrocytes. Trypsin- or papain-treated erythrocytes were prepared as follows: One-tenth volume of $0.5 \%(\mathrm{w} / \mathrm{v})$ trypsin or papain solution was added to a $2 \%$ native erythrocyte suspension, and the mixture was incubated at $37^{\circ} \mathrm{C}$ for $60 \mathrm{~min}$. After incubation, the 
erythrocytes were washed three to five times with saline and a $2 \%$ suspension $(\mathrm{v} / \mathrm{v})$ of trypsin- or papain-treated erythrocytes was prepared as above (Le Dinh Hung et al., 2009a).

\section{Hemagglutination assay}

Hemagglutination assays were carried out using a microtiter method in a 96-well microtiter V-plate (Le Dinh Hung et al., 2009a). Briefly, First, $25 \mu \mathrm{L}$ amounts of serially two-fold dilutions of a test solution were prepared in $20 \mathrm{mM}$ phosphate buffer containing $150 \mathrm{mM} \mathrm{NaCl}(\mathrm{pH}$ 7.2) on a microtiter Vplate. To each well, $25 \mu \mathrm{L}$ of a $2 \%$ erythrocyte suspension was added and the mixtures gently shaken and incubated at room temperature for $2 \mathrm{~h}$. A positive result was indicated by formation of a uniform layer of coagulant over the surface of the well. On the other hand, a negative test result was indicated by the formation of a discrete "button" at the bottom of the well. Hemagglutination activity was expressed as a titer, the reciprocal of the highest two-fold dilution exhibiting positive hemagglutination. The assay was carried out in triplicate for each test solution.

\section{Carbohydrate binding specificity}

Carbohydrate binding specificity were carried according to the method previously described (Le Dinh Hung et al., 2009a). Briefly, first, $25 \mu \mathrm{L}$ of serial two-fold dilutions of sugar or glycoprotein were prepared in $20 \mathrm{mM}$ phosphate buffer containing $150 \mathrm{mM} \mathrm{NaCl}$ ( $\mathrm{pH}$ 7.2). An equal volume of a lectin solution (4 doses of agglutination) was added to each well of plate and plate was mixed gently and allowed to stand at room temperature for $1 \mathrm{~h}$. Finally, $25 \mu \mathrm{L}$ of a $2 \%$ suspension of trypsin-treated rabbit erythrocytes was added to each well, and the plate was gently shaken and incubated for a further $1 \mathrm{~h}$. Carbohydrate binding specificity was expressed as the lowest concentration of sugar $(\mathrm{mM})$ or glycoprotein $(\mu \mathrm{g} / \mathrm{mL})$ at which complete inhibition of hemagglutination (titer 4) was achieved. The test was performed in triplicate per sugar and glycoprotein.

\section{Preparation of trypsin-treated porcine stomach mucin}

Porcine stomach mucin $(10 \mathrm{mg})$ was dissolved in $5 \mathrm{~mL}$ of $20 \mathrm{mM}$ phosphate buffer containing 150 $\mathrm{mM} \mathrm{NaCl}(\mathrm{pH} 7.2)$. Trypsin (5 mg) was added to the sample and the solution obtained was incubated at $37{ }^{\circ} \mathrm{C}$ for $24 \mathrm{~h}$. Treated porcine stomach mucin was heated to $100^{\circ} \mathrm{C}$ for $30 \mathrm{~min}$ then cooled (final reaction volumes were $10 \mathrm{~mL}$ ) and further used as an inhibitor (Xiong et al., 2006). Effects on hemagglutination activity of divalent cations, $\mathrm{pH}$, and temperature

Effects on hemagglutination activity of divalent cations, $\mathrm{pH}$, and temperature were carried according to the method previously described (Le Dinh Hung et al., 2009a). To examine the effects of divalent cations on hemagglutination activity, the lectin solution was dialyzed at $4{ }^{\circ} \mathrm{C}$ overnight against 100 $\mathrm{mL}$ of $50 \mathrm{mM}$ EDTA followed by dialysis against 20 $\mathrm{mM}$ phosphate buffer containing $150 \mathrm{mM} \mathrm{NaCl}(\mathrm{pH}$ 7.5). The hemagglutination activity was determined in the absence or presence of $\mathrm{CaCl}_{2}$. To examine the effect of temperature, each the lectin solution was treated at various temperatures $\left(30-100{ }^{\circ} \mathrm{C}\right)$ for 30 min, then immediately cooled on ice, and hemagglutination activity was determined as above. To examine the effect of $\mathrm{pH}$, each the lectin solution was dialyzed at $4{ }^{\circ} \mathrm{C}$ overnight against $100 \mathrm{~mL}$ of 50 $\mathrm{mM}$ buffers of various $\mathrm{pH}$ from 3 to 10 and then dialyzed against $150 \mathrm{mM} \mathrm{NaCl}$ solution. The following buffers were used including acetate buffer for $\mathrm{pH}$ from 3 to 5, phosphate buffer for $\mathrm{pH}$ from 6 to 7, and Tris- $\mathrm{HCl}$ buffer for $\mathrm{pH}$ from 8 to 10 . Hemagglutination activity was determined with trypsin-treated rabbit erythrocytes. The assay was carried out in triplicate for each test solution.

\section{Determination of protein content}

Protein contents were determined by the method of Lowry et al. (1951) using bovine serum albumin as a standard. Absorbance at $280 \mathrm{~nm}$ was also used to estimate protein contents in chromatography.

\section{Determination of molecular mass}

The molecular mass of purified lectin was determined by sodium dodecyl sulfatepolyacrylamide gel electrophoresis (SDS-PAGE). Briefly, the samples for SDS-PAGE were denatured at $100^{\circ} \mathrm{C}$ for $5 \mathrm{~min}$ with or without $2 \% 2$ mercaptoethanol and then electrophored using a $10 \%$ gel (Laemmli, 1970). After electrophoresis, the gel was stained with Coomassie Brilliant Blue R-250 to detect proteins.

\section{RESULTS AND DISCUSSION}

\section{Extract and purification of lectin}

The ethanol extract of $B$. gelatinus strongly agglutinated trypsin- and papain-treated erythrocytes 
of rabbit, sheep and chicken, but showed no agglutination with erythrocytes of human A, B and O blood groups, even when erythrocytes were treated by enzymes (Table 1).

This study is consistent with other reports on agglutinations preferentially towards the animal erythrocytes more than human ones for marine algal lectin extracts (Chiles, Bird, 1989; Hori et al., 1988, 1990; Ainouz et al., 1992; Freitas et al., 1997; Le Dinh Hung et al., 2009a, 2012). From the ethanol extract, after cold ethanol precipitation and dialysis, the precipitate gave a single active peak in ionexchange chromatography on DEAE Sepharose fast flow column (Figure 1a). The active peak was further separated into two peaks in gel chromatography on a Sephacryl S-200 column. The first peak (I) showed no hemagglutination activity, whereas the second peak (II) exhibited strong hemagglutination activity (Figure 1b). Thus, the purified lectin was designated as BGL after the specific name of alga. The results of purification are summarized in Table 2.

Table 1. Hemagglutination activity of the crude extract from red alga Betaphycus gelatinus.

\begin{tabular}{|c|c|c|c|c|c|c|c|c|c|c|c|c|c|}
\hline \multicolumn{14}{|c|}{ Hemagglutination titer with erythrocytes } \\
\hline Rabbit & Sheep & \multicolumn{3}{|c|}{ Chicken } & \multicolumn{3}{|c|}{ Human A } & \multicolumn{3}{|c|}{ Human B } & \multicolumn{3}{|c|}{ Human O } \\
\hline $\mathrm{N}^{\mathrm{a}} \quad \mathrm{T}^{\mathrm{b}} \quad \mathrm{P}^{\mathrm{c}}$ & $\begin{array}{lll}\mathrm{N} & \mathrm{T} & \mathrm{P}\end{array}$ & $\mathrm{N}$ & $\mathrm{T}$ & $P$ & $\bar{N}$ & $\mathrm{~T}$ & $\bar{P}$ & $\bar{N}$ & $T$ & $\mathrm{P}$ & $\mathrm{N}$ & $T$ & $\mathrm{P}$ \\
\hline
\end{tabular}

${ }^{a}$ Native erythrocytes; ${ }^{b}$ Trypsin-treated erythrocytes; ${ }^{c}$ Papain-treated erythrocytes; ${ }^{d}$ No hemagglutination.

Table 2. The summary of purification of the lectin from B. gelatinus.

\begin{tabular}{|c|c|c|c|c|c|c|}
\hline $\begin{array}{l}\text { Extraction } \\
\text { purification step }\end{array}$ & and & Total Protein (mg) & $\begin{array}{l}\text { Total } \\
\left(\mathrm{HU}^{\mathrm{a}}\right)\end{array}$ & activity & $\begin{array}{l}\text { Specific activity } \\
\left(\mathrm{HU} \mathrm{mg} \mathrm{mg}^{-1}\right)\end{array}$ & $\begin{array}{l}\text { Yield } \\
(\%)\end{array}$ \\
\hline Extraction & & 1141 & 89600 & & 78.5 & 100 \\
\hline Ion exchange & & 59.6 & 13920 & & 233.6 & 15.5 \\
\hline Gel filtration & & 17.7 & 7040 & & 396.8 & 7.8 \\
\hline
\end{tabular}

${ }^{a}$ Total activity is shown by titer $\mathrm{x}$ volume.
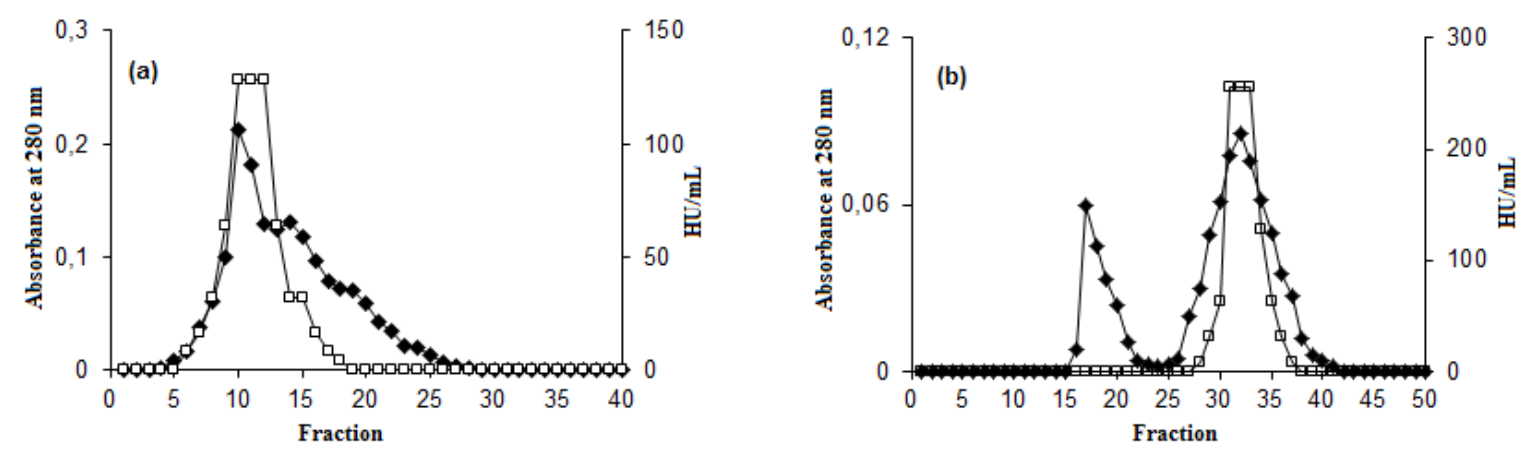

Figure 1. (a) lon-exchange chromatography of the precipitated fraction obtained from crude extract of red alga, $B$. gelatinus on a DEAE Sepharose fast flow column. Lectin was eluted with a linear gradient between 0 to $0.5 \mathrm{M} \mathrm{NaCl}$ in $20 \mathrm{mM}$ carbonate buffer, $\mathrm{pH}$ 9.0. (b) Gel filtration chromatography on a Sephacryl S-200 column of the active peak obtained by ionexchange chromatography. The column was eluted with $50 \mathrm{mM}$ phosphate buffer containing $150 \mathrm{mM} \mathrm{NaCl}, \mathrm{pH} 7.0$. Fractions were collected and measured at absorbance of $280 \mathrm{~nm}(-)$ ) for protein and for hemagglutination activity ( $\square-$ ) with trypsin-treated rabbit erythrocytes. HU hemagglutination unit. 


\section{Determination of molecular mass}

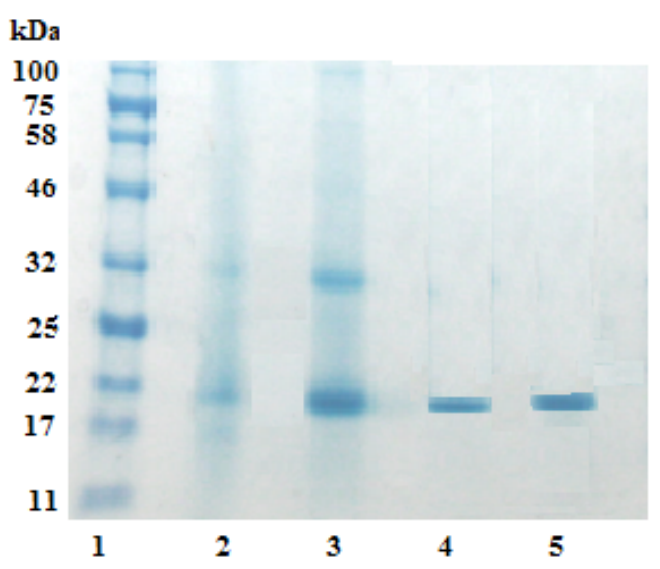

Figure 2. SDS-PAGE of the lectin isolated from red alga B.gelatinus. SDS -PAGE was carried using a $10 \%$ polyacrylamide gel. Protein bands were stained with Coomassie Brilliant blue R-250 reagent. Lane 1, mixture of reference proteins (New England BioLabs Inc); lane 2, $83 \%$ ethanol precipitate; lane 3 , active fractions obtained from ion-exchange chromatography; lane 4, active fractions obtained from gel filtration in non-reducing condition; lane 5, active fractions obtained from gel filtration in reducing condition by $\beta$-mercaptoethanol.

The molecular masses of lectin BGL were estimated to be 19,000 $\mathrm{Da}$ in both reducing and nonreducing SDS-PAGE conditions (Figure 2). The

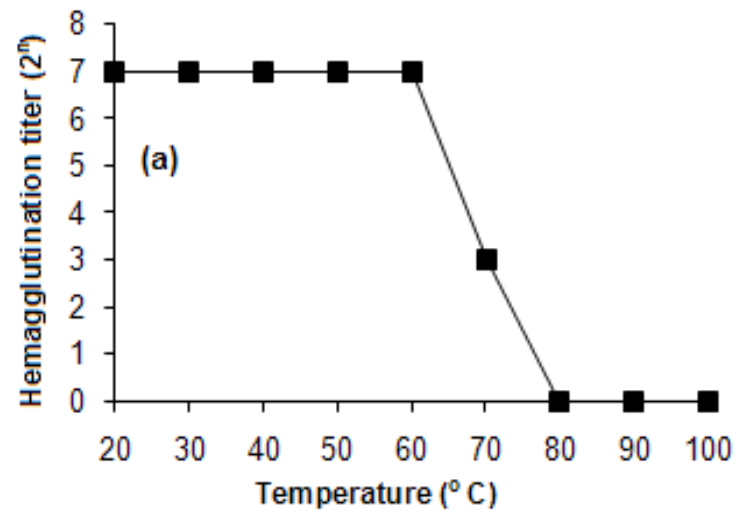

similar results have been reported for lectins from red algae, carrageenophytes, such as E. serra (ESA2) (Hori et al., 2007; Sato et al., 2015), K. alvarezii (KAA-2) (Le Dinh Hung et al., 2009b; Sato et al. 2011a), K. striatum and E. denticulatum (Le Dinh Hung et al., 2011, 2015a) and S. filiformis (SFL) (Chaves et al., 2018), all of them were monomeric proteins in both reducing and non-reducing SDSPAGE conditions, indicating that there was resemblance highly among the lectins of the genus Eucheuma.

\section{Effects of temperature, $\mathrm{pH}$, and metal ions on} hemagglutination activity

The purified lectin is thermostable at $60{ }^{\circ} \mathrm{C}$ for $30 \mathrm{~min}$, where they maintained $100 \%$ of its hemagglutination activity, whereas they gradually decreased as incubation temperature exceeded $60{ }^{\circ} \mathrm{C}$ (Figure 3a). Hemagglutination activity of BGL was stable in a wide range of $\mathrm{pH}$ from 3 to 10 (Figure $3 \mathrm{~b}$ ) and not affected by either the presence of EDTA or addition of divalent cations, indicating that lectin required no metal for biological activity. Thermostable and metal-independent hemagglutination activities have been reported for many lectins from marine algae (Hori et al., 1990; Kawakubo et al., 1997, 1999; Le Dinh Hung et al., 2009a, 2011, 2012, 2015a).

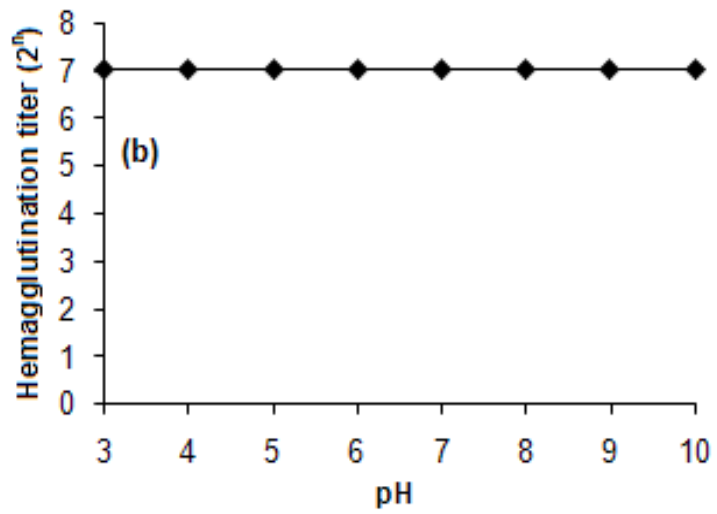

Figure 3. Effects of temperature (a) and $\mathrm{pH}$ (b), respectively, on haemagglutination activities of lectin BGL from red alga $B$. gelatinus.

\section{Carbohydrate binding specificity}

The lectin, BGL, showed the carbohydrate binding specificity profiles with a series of sugars and glycoproteins (Table 3). Hemagglutination activities of BGL were not inhibited by monosaccharides, such as D-glucose, D-mannose, Dgalactose, D-xylose, N-acetyl-glucosamine, N-acetyD-mannosamine, N-acetyl-galactosamine, N-acetylneraminic acid and glycoproteins, such as transferrin, asialo-transferrin and fetuin, but strongly inhibited by glycoproteins bearing high-mannose type $\mathrm{N}$ - 
glycan, such as yeast mannan and porcine thyroglobulin, indicating that the lectin is specific for high-mannose type N-glycans.

Transferrin bearing only complex type Nglycans and fetuin bearing both complex type $\mathrm{N}$ glycans and $\mathrm{O}$-glycans were not inhibitory. However, elimination of sialic acid residues of fetuin increased inhibitory potential compared with parental glycoprotein.
The porcine stomach mucin bearing O-glycans and its asialo derivatives showed inhibitory activity. However, elimination of sialic acid residues of porcine stomach mucin decreased inhibitory potential compared with parental glycoprotein. The O-glycan mucin type has 8 core structures. All are based on the core residue GalNAca1-, which can be further substituted at $\mathrm{C} 3, \mathrm{C} 6$, or at both positions with the monosaccharides $\beta$-Gal at $\mathrm{C} 3, \beta$-GlcNAc at $\mathrm{C} 3$ and/or C6, and $\alpha$-GalNAc at C3 or C6 (Wopereis, 2006).

Table 3. Carbohydrate binding specificity of $B$. gelatinus lectin (BGL).

\begin{tabular}{|c|c|c|c|c|c|c|}
\hline \multirow[t]{2}{*}{ Sugars and glycoproteins } & \multicolumn{6}{|c|}{ Lectins } \\
\hline & BGL & KAA-2 ${ }^{a}$ & KSA-2 ${ }^{b}$ & EDA- $^{c}$ & ESA-2 $^{d}$ & $\mathrm{HRL}^{\mathrm{e}}$ \\
\hline \multicolumn{7}{|l|}{ Sugar (mM) } \\
\hline D-galactose & $-f^{f}$ & - & - & - & - & - \\
\hline $\mathrm{N}$-acetyl-D-galactosamine & - & - & - & - & - & - \\
\hline D-glucose & - & - & - & - & - & - \\
\hline $\mathrm{N}$-acetyl-D-glucosamine & - & - & - & - & - & - \\
\hline D-mannose & - & - & - & - & - & - \\
\hline $\mathrm{N}$-acetyl-D-mannosamine & - & - & - & - & - & - \\
\hline $\mathrm{N}$-acetyl neuraminic acid & - & - & - & - & - & - \\
\hline D-xylose & - & - & - & - & - & - \\
\hline \multicolumn{7}{|l|}{ Glycoproteins $(\mu g / m L)$} \\
\hline Transferrin & - & - & - & - & - & - \\
\hline Asialo-transferrin & - & - & - & - & - & $>1000$ \\
\hline Fetuin & - & 31.2 & 31.2 & 62.5 & 62.5 & $>1000$ \\
\hline Asialo-fetuin & 125.0 & 31.2 & 31.2 & 125.0 & 31.2 & $>1000$ \\
\hline Yeast mannan & 7.8 & 3.9 & 1.9 & 3.9 & 3.9 & 15.6 \\
\hline Porcine thyroglobulin & 7.8 & 1.9 & 0.9 & 1.9 & 3.9 & 62.5 \\
\hline Porcine stomach mucin & 125.0 & - & - & - & ND & ND \\
\hline Asialo-porcine stomach mucin & 250.0 & - & - & - & ND & ND \\
\hline Trypsin treated porcine stomach mucin & 250.0 & - & - & - & ND & ND \\
\hline
\end{tabular}

a'Lectin KAA-2 from Kappaphycus alvarezzi alga (Le Dinh Hung et al., 2009b); ${ }^{b}$ Lectin KSA-2 from Kappaphycus striatum alga (Le Dinh Hung et al., 2011):; ' Lectin EDA-2 from Eucheuma denticulatum alga (Le Dinh Hung et al., 2015a); ${ }^{d}$ Lectin ESA-2 from Eucheuma serra alga (Kawakubo et al., 1997); ${ }^{e}$ Lectin HRL from Halimeda renschii alga (Mu et al., 2017). Indicates no inhibition at $100 \mathrm{mM}$ for monosaccharides and $2,000 \mu \mathrm{g} / \mathrm{mL}$ for glycoproteins. ND not determined.

The yeast mannan, which bearing high mannose $\mathrm{N}$-glycans with the ( $\alpha 1-6)$ linkage in its backbone and $(\alpha 1-3)$ linkage in the side chains showed strongly inhibitory activity, indicating that lectin BGL could recognize the ( $\alpha 1-6)$ and ( $\alpha 1-3)$-linked Man residues in structures of yeast mannan (Figure 4). Porcine thyroglobulin exhibited strongly inhibitory activity. This glycoprotein bears both high mannose type (unit A-type) and complex type (unit B-type) oligosaccharides. Among the unit A-type of porcine thyroglobulin, the common structure of high mannose type N-glycans is $\mathrm{Man}_{5} \mathrm{GlcNAc}_{2} \mathrm{Asn}$ with ( $\alpha 1-6)$ Man and ( $\alpha 1-3)$ Man residues branched from ( $\alpha 1-6)$ Man arm of the core pentasaccharide (Tsuji et al., 1981). Among the unit B-type, the major Nglycans contain at least 9 different structures consisting of mono- and disialylated ( $\alpha 1-6)$ fucosylated bi-, triantennary structures terminated either with $(\alpha 2-3)$ or ( $\alpha 2-6)$-linked sialic acid residues (Yamamoto et al., 1981). The results 
indicated that BGL could recognize terminated either with $(\alpha 1-3)$ or $(\alpha 1-6)$-linked mannose residues in structure $\operatorname{Man}(\alpha 1-6)[\operatorname{Man}(\alpha 1-3)] \operatorname{Man}(\alpha 1-$ 6) $[\operatorname{Man}(\alpha 1-3)] \quad \operatorname{Man}(\beta 1-4) \operatorname{GlcNAc}(\beta 1-4)$ GlcNAcof yeast mannan and porcine thyroglobulin (unit Atype) (Figure 4).

Inhibition by yeast mannan and porcine thyroglobulin that is related to high-mannose type $\mathrm{N}$ glycan binding specificity reported for many antiHIV, anti-influenza virus, anti-cancer and antibacteria lectins from marine algae, such as E. serra
(ESA-2) (Fukuda et al., 2006; Hori et al., 2007; Omokawa et al., 2010; Hayashi et al., 2012; Sato et al., 2015; ), K. alvarezii (KAA-2) (Sato et al., 2011a; Hirayama et al., 2016), B. coacta (BCA) (Sato et al., 2011b), K. striatum, E. denticulatum (Le Dinh Hung et al., 2015a, 2015b), H. renschii (HRL) (Mu et al., 2017) and S. filiformis (SFL) (Chaves et al., 2018), all of them were specific for high-mannose type Nglycans. Thus, high-mannose binding lectins from marine algae may become a useful interesting target for application in medicine.

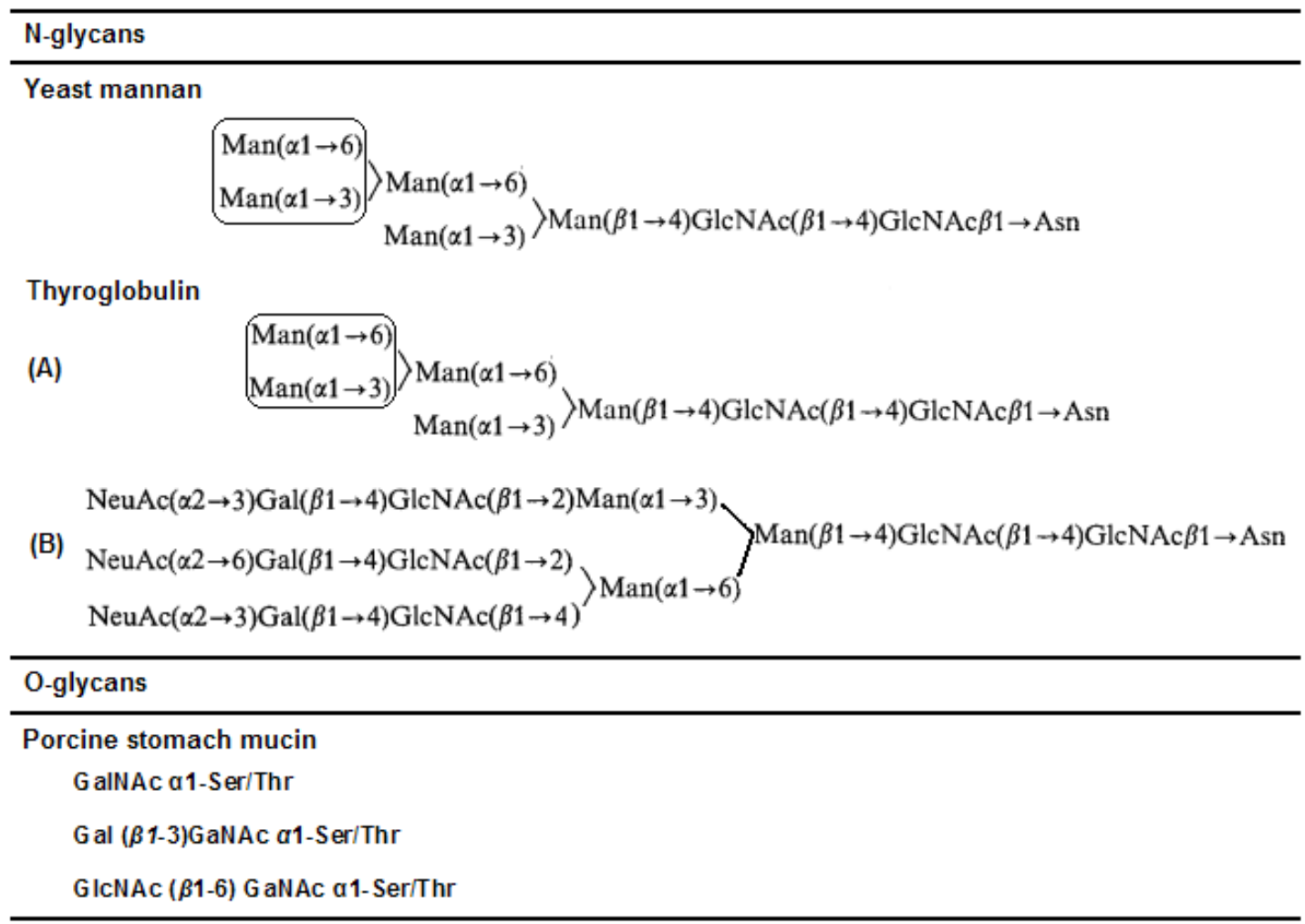

Figure 4. The putative epitopes recognized by lectin from red alga B. gelatinus are highlighted in rectangle. Man: Mannose; Gal: Galactose; Fuc: Fucose; GlcNAc: N-acetyl-D-glucosamine; GalNAc: N-acetyl-D-galactosamine, NeuAc: Nacetylneuraminic acid; Asn: Asparagine; Ser/Thr: Serine/Threonine.

\section{CONCLUSION}

The lectin BGL from red alga $B$. gelatinus showed novel properties, including molecular mass, monomeric form, hemagglutination-inhibition profile, and stable over a wide range of $\mathrm{pH}$ and temperature. BGL preferably bond to terminal $(\alpha 1-$ $3)$ or ( $\alpha 1-6)$-linked mannose residues in structure $\mathrm{Man}_{5} \mathrm{GlcNAc}_{2} \mathrm{Asn}$ of N-glycans, indicating that the terminal $(\alpha 1-3)$ or $(\alpha 1-6)$-linked mannose residues in N-glycans were critical for lectin binding. Thus, the red alga $B$. gelatinus promises to be a source of novel lectin ( $\mathrm{s}$ ) for application in biochemistry and biomedicine.

Acknowledgements: This research was supported by the International cooperation program between Vietnam Academy of Science and Technology (VAST) and Pacific Institute of Bioorganic Chemistry, Far Eastern Branch of the Russian 
Academy of Sciences, Russia (FEBRAS) under grant number QTRU02.04/18-19.

\section{REFERENCES}

Ainouz IL, Sampaio AH, Benevides NMB, Freitas ALP, Costa FHF, Carvalho MC, Pinheiro-Joventino F (1992) Agglutination of enzyme treated erythrocytes by Brazilian marine algae. Bot Mar 35: 475-479.

Balzarini J (2007) Carbohydrate-binding agents: a potential future cornerstone for the chemotherapy of enveloped viruses? Antivir Chem Chemother 18: 1-11.

Chaves RP, da Silva SR, Neto LGN, Carneiro RF, da Silva ALC, Sampaio AH, de Sousa BL, Cabral MG, Videira PA, Teixeira EH, Nagano CS (2018) Structural characterization of two isolectins from the marine red alga Solieria filiformis (Kützing) P.W. Gabrielson and their anticancer effect on MCF-7 breast cancer cells. Int J Biol Macromol 107: $1320-1329$.

Chiles TC, Bird KT (1989) A comparative study of the animal erythrocyte agglutinins from marine algae. Comp Biochem Physiol 94B: 107-111.

Dinh Thanh Trung, Vo Thi Dieu Trang, Ngo Thi Duy Ngoc, Phan Thi Hoai Trinh, Tran Thi Hai Yen, Le Dinh Hung (2017) Haemagglutination activity of the extracts from some Vietnam marine invertebrates. Vietnam $J$ Biotechnol 15(4): 691-701.

Freitas ALP, Teixeira DIA, Costa FHF, Farias WRL, Lobato ASC, Sampaio AH, Benevides NMB (1997) A new survey of Brazilian marine algae for agglutinins. $J$ Appl Phycol 9: 495-501.

Fukuda Y, Sugahara T, Ueno M, Fukuta Y, Ochi Y, Akiyama K, Miyazaki T, Masuda S, Kawakubo A, Kato K (2006) The anti-tumor effect of Euchema serra agglutinin on colon cancer cells in vitro and in vivo. Anti-Cancer Drugs 17: 943-947.

Hayashi K, Walde P, Miyazaki T, Sakayama K, Nakamura A, Kameda K, Masuda S, Umakoshi H, Kato K (2012) Active targeting to osteosarcoma cells and apoptotic cell death induction by the novel lectin Eucheuma serra agglutinin isolated from a marine red alga. J Drug Deliv doi:10.1155/2012/842785.

Hirayama M, Shibata H, Imamura K, Sakaguchi T, Hori K (2016) High-mannose specific lectin and its recombinants from a Carrageenophyta Kappaphycus alvarezii represent a potent anti-HIV activity through high-affinity binding to the viral envelope glycoprotein gp120. Mar Biotechnol 18: 144-160.

Hori K, Oiwa C, Miyazawa K, Ito K (1988) Evidence for wide distribution of agglutinins in marine algae. Bot Mar 31: 133-138.

Hori K, Miyazawa K, Ito K (1990) Some common properties of lectins from marine algae. Hydrobiologia 204/205: 561-566.

Hori K, Sato Y, Ito K, Fujiwara Y, Iwamoto Y, Makino H, Kawakubo A (2007) Strict specificity for high-mannose type $\mathrm{N}$-glycans and primary structure of a red alga Eucheuma serra lectin. Glycobiology 17: 479-491.

Huynh Quang Nang, Nguyen Huu Dinh (1998) The seaweed resources of Vietnam. In: Critchley AT, Ohno M (eds) Seaweed resources of the World. JICA, Japan pp: 62-69.

Kawakubo A, Makino H, Ohnishi J, Hirohara H, Hori K (1997) The marine red alga Eucheuma serra J Agardh, a high yielding source of two isolectins. J Appl Phycol 9: 331-338.

Kawakubo A, Makino H, Ohnishi J, Hirohara H, Hori K (1999) Occurrence of highly yielded lectins homologous within the genus Eucheuma. J Appl Phycol 11: 149-156.

LaemmLi UK (1970) Cleavage of structural proteins during the assembly of the head of bacteriophage T4. Nature 227: 680-685.

Le Dinh Hung, Hori K, Huynh Quang Nang (2009a) Screening and preliminary characterization of hemagglutinins in Vietnamese marine algae. J Appl Phycol 21: 89-97.

Le Dinh Hung, Sato T, Shibata H, Hori K (2009b) Biochemical comparison of lectins among three different color strains of the red alga Kappaphycus alvarezii. Fish Sci 75: 723-730.

Le Dinh Hung, Hori K, Huynh Quang Nang, Tran Kha, Le Thi Hoa (2009c) Seasonal changes in growth rate, carrageenan yield and lectin content in the red alga Kappaphycus alvarezii cultivated in Camranh Bay, Vietnam. J Appl Phycol 21: 265-272.

Le Dinh Hung, Sato Y, Hori K (2011) High-mannose Nglycan-specific lectins from the red alga Kappaphycus striatum (Carrageenophyte). Phytochemistry 72: 855-861.

Le Dinh Hung, Bui Minh Ly, Vo Thi Dieu Trang, Ngo Thi Duy Ngoc, Le Thi Hoa, Phan Thi Hoai Trinh (2012) A new screening for hemagglutinins from Vietnamese marine macroalgae. J Appl Phycol 24: 227-235.

Le Dinh Hung, Ngo Thi Duy Ngoc, Kanji Hori (2013) Isolation and characterization of novel lectins from the red alga Gracilaria salicornia. Vietnam J Biotechnol 11(4): $743-753$

Le Dinh Hung, Hirayama M, Bui Minh Ly, Hori K (2015a) Purification, primary structure, and biological activity of high-mannose $N$-glycan-specific lectin from the cultivated Eucheuma denticulatum. J Appl Phycol 27: 1657-1669.

Le Dinh Hung, Hirayama M, Bui Minh Ly, Hori K (2015b) Biological activity, cDNA cloning and primary structure of lectin KSA-2 from the cultivated red alga 
Kappaphycus striatum (Schmitz) Doty ex Silva. Phytochem Lett 14: 99-105.

Le Dinh Hung, Hirayama M, Hori K (2016) Cloning and characterizing cDNA sequences coding high-mannose Nglycan binding lectins from cultivated red algae Eucheuma denticulatum and Kappaphycus striatum. Vietnam $J$ Biotechnol 14: 327-336.

Le Dinh Hung, Tran Thi Hai Yen, Dinh Thanh Trung (2018a) Characterization of O-glycan binding lectin from the red alga Hydropuntia eucheumatoides. Vietnam $J$ Biotechnol 16(4): 687-696.

Le Dinh Hung, Bui Minh Ly, Vo Thi Hao, Dinh Thanh Trung, Vo Thi Dieu Trang, Phan Thi Hoai Trinh, Ngo Thi Duy Ngoc, Thai Minh Quang (2018b) Purifcation, characterization and biological effect of lectin from the marine sponge Stylissa flexibilis (Lévi, 1961). Com Biochem Physiol Part B 216: 32-38.

Le Dinh Hung, Le Thi Hoa, Le Nhu Hau, Dinh Thanh Trung (2019) The lectin accumulation, growth rate, carrageenan yield, and quality from the red alga Kappaphycus striatus cultivated at Camranh Bay, Vietnam. J Appl Phycol 31: 1991-1998.

Lowry OH, Rosebrough NJ, Farr AL, Randall RJ (1951) Protein measurement with the Folin phenol reagent. J Biol Chem 193: 265-275.

Mu J, Hirayama M, Sato Y, Morimoto K, Hori K (2017) A novel high-mannose specific lectin from the green alga Halimeda renschii exhibits a potent anti-influenza virus activity through high-affinity binding to the viral hemagglutinin. Mar Drugs doi:10.3390/md15080255.

Omokawa Y, Miyazaki T, Walde P, Akiyama K, Sugahara T, Masuda S, Inada A, Ohnishi Y, Saeki T, Kato K (2010) In vitro and in vivo anti-tumor effects of novel Span 80 vesicles containing immobilized Eucheuma serra agglutinin. Int $J$ Pharm 389: 157-167. Sato Y, Morimoto K, Hirayama M, Hori K (2011a) High mannose-specific lectin (KAA-2) from the red alga Kappaphycus alvarezii potently inhibits influenza virus infection in a strain-independent manner. Biochem Biophys Res Commun 405: 291-296.

Sato Y, Hirayama M, Morimoto K, Yamamoto N, Okuyama S, Hori K (2011b) High mannose-binding lectin with preference for the cluster of $\alpha 1-2$-mannose from the green alga Boodlea coacta is a potent entry inhibitor of HIV-1 and influenza viruses. J Biol Chem 286: 19446 19458.

Sato Y, Morimoto K, Kubo T, Sakaguchi T, Nishizono A, Hirayama M, Hori K (2015) Entry inhibition of influenza viruses with high mannose binding lectin ESA-2 from the red alga Eucheuma serra through the recognition of viral hemagglutinin. Mar Drugs 13: 3454-3465.

Sharon N, Lis H (2003) Lectins, second ed. Kluwer Academic Publishers, The Netherlands

Sugawara T, Ohama Y, Fukuda A, Hayashi M, Kato K (2001) The cytotoxic effect of Eucheuma serra agglutinin (ESA) on cancer cells and its application to molecular probe for drug delivery system using lipid vesicles. Cytotechnology 36: 93-99.

Tsuji T, Yamamoto K, Irimura T, Osawa T (1981) Structure of carbohydrate unit A of porcine thyroglobulin. J Biochem 195: 691-699.

Wopereis S, Lefeber DJ, Morava E, Wevers RA (2006) Mechanisms in protein O-glycan biosynthesis and clinical and molecular aspects of protein O-glycan biosynthesis defects: A Review. Clinical Chemistry 52: 574-600.

Xiong C, Li W, Liu H, Zhang W, Dou J, Bai X, Du Y, Ma $\mathrm{X}$ (2006) A normal mucin-binding lectin from the sponge Craniella australiensis. Comp Biochem Physiol, Part C 143: 9-16.

Yamamoto K, Tsuji T, Irimura T, Osawa T (1981) The structure of carbohydrate unit B of porcine thyroglobulin. $J$ Biochem 195: 701-713.

Ziólkowska NE, Wlodawer A (2006) Structural studies of algal lectins with anti-HIV activity. Acta Biochim Pol 53: $617-626$.

\section{ĐẶC TÍNH LIÊN KẾT N-GLYCAN DẠNG HIGH-MANNOSE CỦA LECTIN MỚI TỬ RONG ĐỎ BETAPHYCUS GELATINUS}

\section{Lê Đình Hùng ${ }^{1}$, Lê Thị Đoan Thục ${ }^{2}$}

${ }^{1}$ Viện Nghiên cưu và Úng dụng Công nghệ Nha Trang, Viện Hàn lâm Khoa học và Công nghệ Việt Nam

${ }^{2}$ Truờng Trung hoc phổ thông Lý Tự Trọng, Khánh Hòa

\section{TÓM TẮT}

Rong đỏ, Betaphycus gelatinus là một trong những nguồn carrageenan trên thế giới. Lectin BGL được đặt tên theo tên của mẫu rong đã được tách chiết bằng sự kết hợp dịch chiết ethanol, kết tủa ethanol, sắc ký trao đổi ion và sắc ký lọc gel. Lectin thể hiện một dải đơn với khối lượng phân tử khoảng 19.000 Da trong cả hai điều kiện điện di gel polyacrylamide không biến tính (SDS-PAGE) và biến tính, chỉ ra rằng lectin tồn tại ở dạng 
monome. Hoạt tính ngưng kết hồng cầu của BGL bền trong một phạm vi rộng của nhiệt độ, $\mathrm{pH}$ và không bị ảnh hưởng bởi sự có mặt của EDTA hoặc thêm cation hóa trị hai như $\mathrm{Ca}^{2+}$ và $\mathrm{Mg}^{2+}$, vì vậy hoạt tính sinh học của lectin không phụ thuộc vào kim loại. Hoạt tính ngưng kết hồng cầu của lectin BGL không bị ức chế bởi các đường monosaccharide và glycoprotein, D-glucose, D-mannose, D-galactose, D-xylose, N-acetylgalactosamine, N-acetyl-glucosamine, N-acetyl-neuraminic acid, N-acety-D-mannosamine, transferin and fetuin, nhưng bị ức chế mạnh bởi các glycoproteins mang $\mathrm{N}$-glycan dạng high-mannose như yeast mannan và porcine thyroglobulin. Lectin BGL đặc hiệu với $\mathrm{N}$-glycan và có thể nhận biết các gốc mannose được liên kết $(\alpha 1-3)$ hoặc $(\alpha 1-6)$ ở vị trí cuối cùng trong cấu trúc $\operatorname{Man}(\alpha 1-6)[\operatorname{Man}(\alpha 1-3)] \operatorname{Man}(\alpha 1-6)[\operatorname{Man}(\alpha 1-3)] \operatorname{Man}(\beta 1$ 4)GlcNAc( $(\beta 1-4)$ GlcNAc của N-glycan. Đặc tính liên kết N-glycan dạng high-mannose của lectin BGL tương tự với đặc tính liên kết $\mathrm{N}$-glycan dạng high-mannose của các lectin có hoạt tính kháng virus, kháng ung thư và kháng vi khuẩn từ các lòai rong đỏ, carrageenophyte, như Eucheuma serra (ESA-2), Eucheuma denticulatum (EDA-2), Kappaphycus striatum (KSA-2), Kappaphycus alvarezii (KAA-1 and KAA-2) và Solieria filiformis (SfL). Rong đỏ $B$. gelatinus hứa hẹn là một nguôn lectin giá trị để sử dụng trong hóa sinh và y sinh.

Tù̀ khóa: Betaphycus gelatinus; Đặc tính liên kết carbohydrate; Lectin; N-glycan dạng high-mannose; Rong đỏ 